\title{
Radical heterocyclization and heterocyclization cascades triggered by electron transfer to amide-type carbonyls
}

DOI:

10.1002/anie.201708354

\section{Document Version}

Accepted author manuscript

Link to publication record in Manchester Research Explorer

\section{Citation for published version (APA):}

Huang, H., \& Procter, D. (2017). Radical heterocyclization and heterocyclization cascades triggered by electron transfer to amide-type carbonyls. Angewandte Chemie, 56(45), 14262-14266.

https://doi.org/10.1002/anie.201708354

\section{Published in:}

Angewandte Chemie

\section{Citing this paper}

Please note that where the full-text provided on Manchester Research Explorer is the Author Accepted Manuscript or Proof version this may differ from the final Published version. If citing, it is advised that you check and use the publisher's definitive version.

\section{General rights}

Copyright and moral rights for the publications made accessible in the Research Explorer are retained by the authors and/or other copyright owners and it is a condition of accessing publications that users recognise and abide by the legal requirements associated with these rights.

\section{Takedown policy}

If you believe that this document breaches copyright please refer to the University of Manchester's Takedown Procedures [http://man.ac.uk/04Y6Bo] or contact uml.scholarlycommunications@manchester.ac.uk providing relevant details, so we can investigate your claim.

\section{OPEN ACCESS}




\section{Radical heterocyclization and heterocyclization cascades triggered by electron transfer to amide-type carbonyls}

\author{
Huan-Ming Huang and David J. Procter*
}

\begin{abstract}
Radical heterocyclizations triggered by electron transfer to amide-type carbonyls using $\mathrm{Sml}_{2}-\mathrm{H}_{2} \mathrm{O}$ provides straightforward access to bicyclic heterocyclic scaffolds containing bridgehead nitrogens. Furthermore, the first radical heterocyclization cascades triggered by reduction of amide-type carbonyls deliver novel, complex tetracyclic architectures containing five contiguous stereocenters with excellent diastereocontrol.
\end{abstract}

Polycyclic, heterocycle-containing architectures possessing bridgehead nitrogen atoms are found widely in natural and unnatural compounds of biological significance, including nucleic acids, drug molecules and natural products (Figure 1). ${ }^{[1]}$ Developing expedient new methods to construct such systems is an important goal in synthetic and medicinal chemistry. ${ }^{[2]}$ For example, recent advances in the one-step construction of polycyclic systems possessing bridgehead nitrogens include the $[4+2] /[3+2]$ cycloaddition cascades of Boger, $^{[3]}$ the $\mathrm{Rh}(\mathrm{II})$ catalyzed cyclization/[3+2] cycloaddition cascades of Padwa ${ }^{[4]}$ and Zhai, ${ }^{[5]}$ and Movassaghi's double intramolecular trapping of iminium ions. ${ }^{[1 \mathrm{~m}]}$ Perhaps due to the challenge associated with the control of selectivity in the reactions of highly reactive open shell intermedates, the otherwise desirable use of radical cyclizations and cyclization cascades to assemble such systems is rare. ${ }^{[10,6]}$

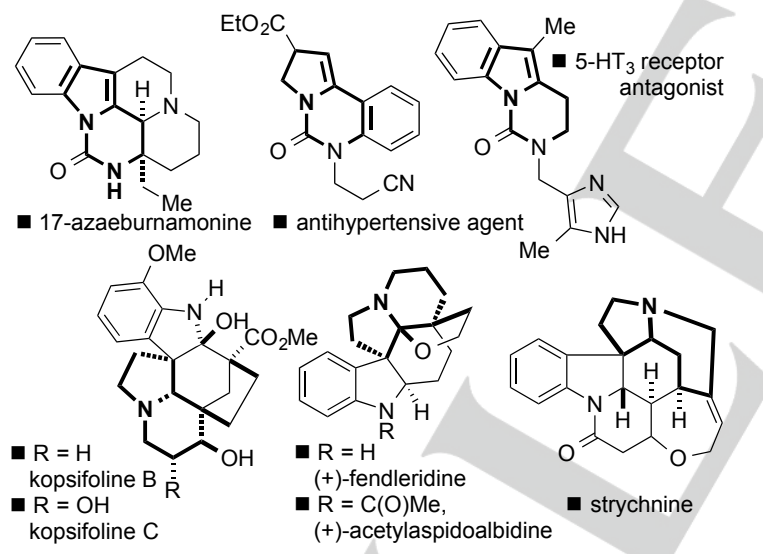

Figure 1. Selected polycyclic, heterocycle-containing architectures of biological importance that contain bridgehead nitrogen atoms.

Radical cyclizations are a powerful synthetic approach for the construction of carbo- and heterocyclic systems ${ }^{[7]}$ Samarium diiodide $\left(\mathrm{Sml}_{2}\right.$, Kagan's reagent) is a selective, versatile, and commercially available or readily-prepared electron transfer (ET) reductant. ${ }^{[8]}$ It is particularly adept at mediating radical carbocyclization processes involving ketyl radicals but this is

[*] H. -M. Huang, Prof. Dr. D. J. Procter

School of Chemistry, University of Manchester

Manchester, M13 9PL (UK)

E-mail: david.j.procter@manchester.ac.uk

Supporting information for this article is given via a link at the end of the document.((Please delete this text if not appropriate)) largely limited to radicals generated from ketones or aldehydes (Scheme 1A). ${ }^{[8]}$ Recently, we described how $\mathrm{Sml}_{2}$, when activated by $\mathrm{H}_{2} \mathrm{O}$, can execute the challenging ET reduction of cyclic esters, and have exploited the unusual ketyl radicals formed in new radical carbocyclizations. ${ }^{[9]}$ The ubiquitous amide moiety $^{[10]}$ is even more resistant to ET reduction and the development of new radical cyclization methods based on the reduction of amide derivatives presents a significant challenge. Inspired by the pioneering work of Reissig, ${ }^{[11]}$ Skrydstrup, ${ }^{[12]}$ $\mathrm{Py},{ }^{[13]}$ and Huang ${ }^{[13 a, 14]}$ on $\mathrm{Sml}_{2}$-mediated nitrogen heterocycle synthesis (Scheme 1A), ${ }^{[15,16]}$ herein, we describe radical heterocyclizations $^{[16 \mathrm{~d}-\mathrm{f}]}$ and the first radical heterocyclization cascades of amide-type substrates. The $\mathrm{Sml}_{2}-\mathrm{H}_{2} \mathrm{O}$ mediated radical processes involve the coupling of amide carbonyls and alkenes, tethered through an $\mathrm{sp}^{2}$-hybridized nitrogen, and provide expedient access to important polycyclic heterocycles possessing bridgehead nitrogen atoms (Figure 1 \& Scheme 1B).

A. $\mathrm{Sml}_{2}$-mediated radical cyclizations involving ketyl radicals

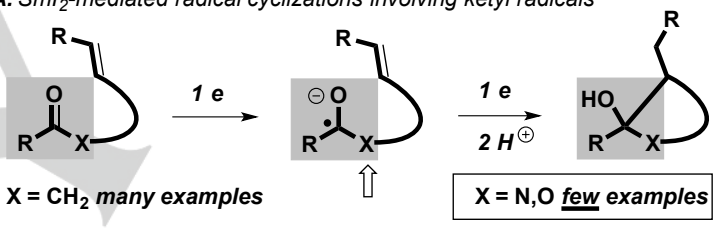

B. $\mathrm{SmI}_{2}$-mediated radical heterocyclizations of amide derivatives (this work)

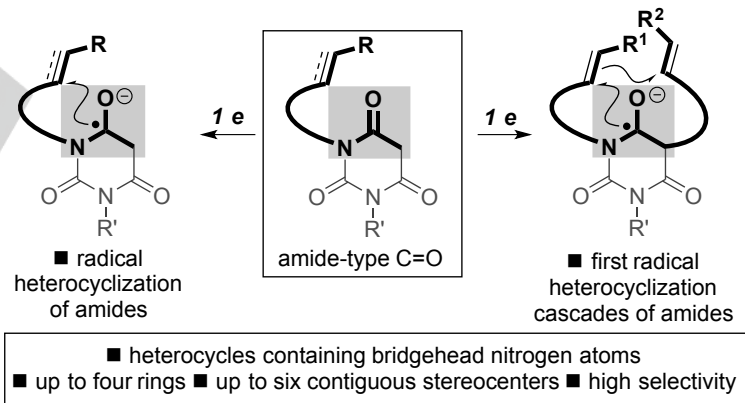

Scheme 1. (A) Ketyl radical cyclizations mediated by $\mathrm{Sml}_{2}$. (B) This work: $\mathrm{Sml}_{2}$-mediated heterocyclization and heterocyclization cascades triggered by ET reduction of amide-type carbonyls.

Substrate 1a, possessing an alkene radical trap attached via nitrogen, was readily synthesised in one step from commercial barbituric acid and 4-phenyl-but-3-en-1-ol. After careful optimization (see Supporting Information), ${ }^{[17]}$ slow addition of $\mathrm{Sml}_{2}$ (3 equivalents over 1 hour) to $1 \mathrm{a}$ and water (100 equiv) gave heterocyclization/dehydration product $2 \mathbf{a}$ in $78 \%$ isolated yield.

Various substituents, including fluoro (2c and $2 \mathbf{e})$, methyl (2d), methoxy (2f and $\mathbf{2 i})$, chloro (2g), bromo (2h), trifluoromethyl (2j), thienyl $(\mathbf{2 k})$ and naphthyl (2l), were compatible with the radical heterocyclization and products were obtained in good to excellent isolated yield (Table 1). Larger alkyl groups at C2 of the barbituric acid unit were also tolerated: 2b was obtained in $50 \%$ isolated yield. A larger scale experiment $(2 \mathrm{mmol}, 0.84 \mathrm{~g}$ of $\mathbf{1 a}$ ) gave the product $\mathbf{2 a}$ in $70 \%$ yield after $2 \mathrm{~h}(0.56 \mathrm{~g})$. Treatment of $1 \mathrm{a}$ with $\mathrm{D}_{2} \mathrm{O}$ in combination 
with $\mathrm{Sml}_{2}$ gave the labeled product $\mathbf{2 a}-\mathbf{D}$ in $65 \%$ isolated yield, thus confirming that the process is terminated by protonation of a benzylic organosamarium.

Table 1. Scope of the radical heterocyclization to form bicyclic enamines containing bridgehead nitrogens $\mathbf{2}^{a, b}$

$$
\left[\mathrm{R}^{\prime}=\mathrm{CH}_{2} \mathrm{CH}_{2} \mathrm{CH}=\mathrm{CHAr}\right]
$$

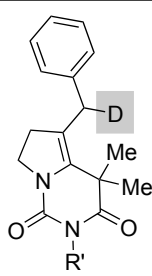

$2 \mathrm{a}-\mathrm{D}, 65 \%^{\mathrm{d}}$ $(97 \%$ incorp. $)$
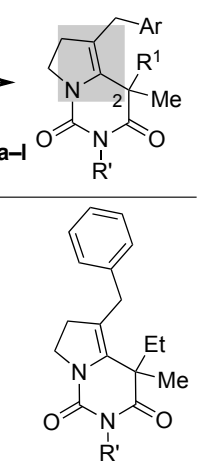

2b, $50 \%{ }^{\mathrm{e}}$
$2 \mathrm{mmol}$ scale $-0.56 \mathrm{~g}, 70 \%^{\mathrm{c}}$

$$
A r=2 c R=F, 50 \%
$$

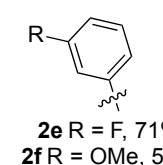

2f $\mathrm{R}=\mathrm{OMe}, 53 \%$

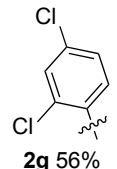

$\mathrm{R}$

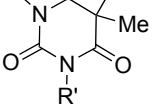

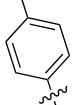

2h $\mathrm{R}=\mathrm{Br}, 72 \%$

2i R $=\mathrm{OMe}, 58 \%$

$2 \mathrm{j} R=\mathrm{CF}_{3}, 75 \%$

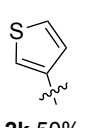

2k $50 \%$

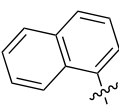

2I $45 \%$

[a] Reaction conditions: To the substrate $\left(0.1 \mathrm{mmol}\right.$, in THF) under $\mathrm{N}_{2}$ was added $\mathrm{H}_{2} \mathrm{O}$ (100 equiv), followed by slow addition of $\mathrm{Sml}_{2}$ in THF (3 equiv) over $1 \mathrm{~h}$. The reaction was then quenched after a further $1 \mathrm{~h}$. [b] Isolated yields. [c] Result of a larger scale experiment $(2 \mathrm{mmol})$. [d] $\mathrm{D}_{2} \mathrm{O}$ was used rather than $\mathrm{H}_{2} \mathrm{O}$. [e] 4 equiv $\mathrm{Sml}_{2}$ was used.

Alkyne radical traps could also be used in the radical amide heterocyclization. In this approach, unusual bicyclic hemiaminals were obtained in good isolated yield and as single double bond isomers (Table 2). Notably, a 6-exo-dig radical heterocyclization was also possible and $2 p$ was obtained in $44 \%$ yield. An alkynylsilane acceptor also proved compatible with the process and vinylsilane $2 q$ was obtained in $52 \%$ yield. X-ray crystallographic analysis confirmed the structure of product 2n. ${ }^{[18]} E$-alkene isomers are thought to arise from selective formation and protonation of vinyl samarium intermediates in which samarium coordinates to the oxygen of the hemiaminal moiety. ${ }^{[15]}$ With the exception of $\mathbf{1 q}$, the presence of an aryl substituent on the alkene or alkyne has so far proved important for efficient cyclization.

Table 2. Scope of the radical heterocyclization to form bicyclic hemiaminals containing bridgehead nitrogens $2^{a, b}$
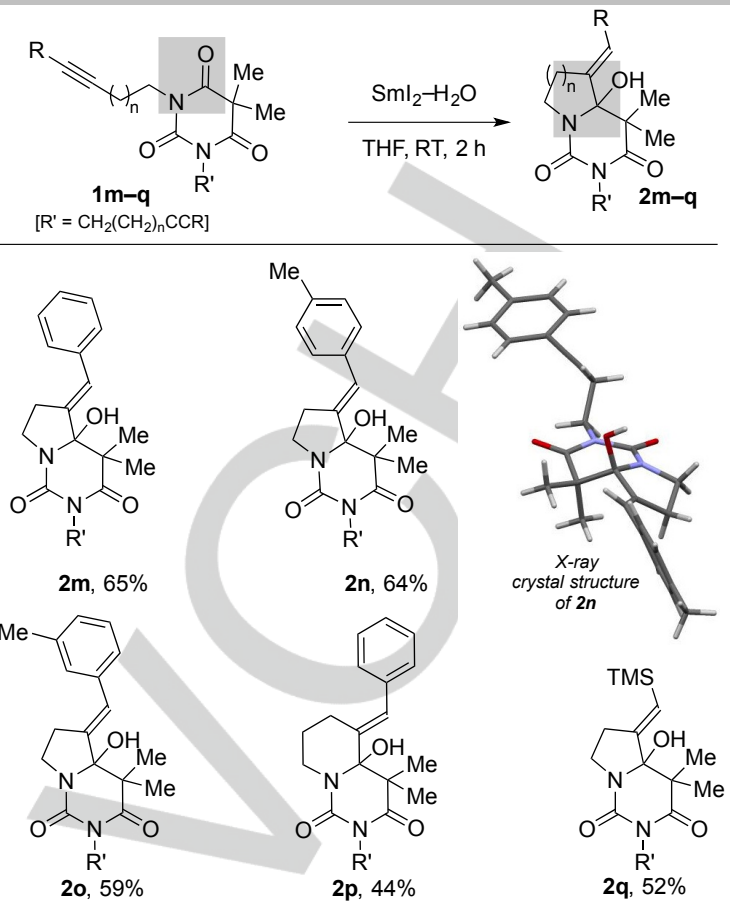

[a] Reaction conditions: To the substrate $\left(0.1 \mathrm{mmol}\right.$, in THF) under $\mathrm{N}_{2}$ was added $\mathrm{H}_{2} \mathrm{O}$ (80 equiv), followed by slow addition of $\mathrm{Sml}_{2}$ in THF (4 equiv) over $1 \mathrm{~h}$. The reaction was quenched after a further $1 \mathrm{~h}$. [b] Isolated yields.

The radical heterocyclization of $\mathbf{1 a}$ proceeds by reductive ET to the amide-type carbonyl to generate radical $3 .{ }^{[15,16]} 5$-Exo-trig cyclization and dehydration via acyl iminium ion intermediate 4 delivers bicyclic enamine 2a. 5-exo-dig cyclization of the radical derived from $1 \mathrm{~m}$ gives vinyl radical intermediate 5 that upon further reduction and protonation gives bicyclic hemiaminal $\mathbf{2 m}$ (Scheme 2).

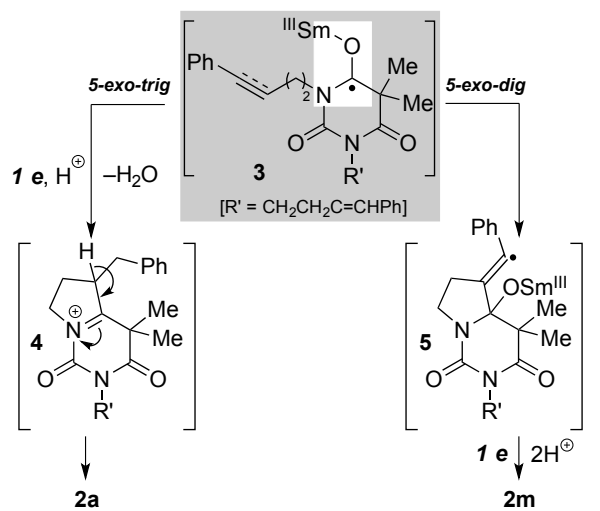

Scheme 2. Proposed mechanism for the radical heterocyclizations.

The bicyclic hemiaminal products are versatile building blocks for synthesis: ${ }^{[19]}$ treatment of $2 \mathrm{~m}$ with $\mathrm{Et}_{3} \mathrm{SiH}$ and $\mathrm{BF}_{3} \cdot \mathrm{OEt}_{2}$ gave 1,2-addition product $6(90 \%$ yield $)$ while exposure of $2 \mathrm{~m}$ to allyITMS and $\mathrm{BF}_{3} \cdot \mathrm{OEt}_{2}$ gave 1,4-addition product 7 ( $82 \%$ yield) (Scheme 3 ). 


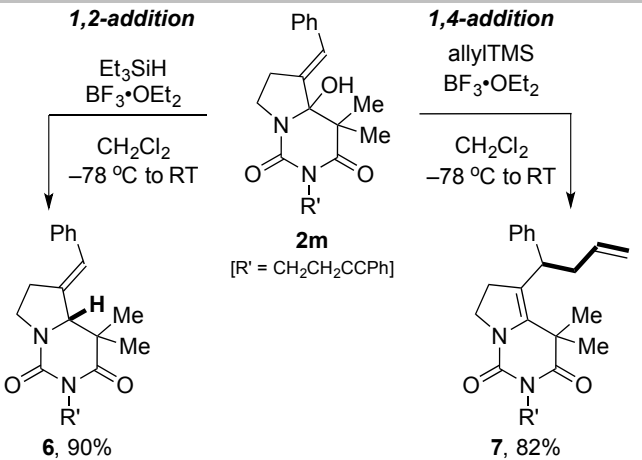

Scheme 3. Manipulation of bicyclic hemiaminal $2 \mathrm{~m}$

Cyclization cascades have the potential to convert simple starting materials to complex polycyclic molecular frameworks in one step. ${ }^{[20]}$ Barbiturate $\mathbf{8 a}$ was synthesized in three straightforward steps from diethyl 2,2-diallylmalonate and was used to explore the feasibility of a radical hetero- then carbocyclization cascade to construct complex, polycyclic hemiaminals containing bridgehead nitrogens (cf. Scheme 1B). Exposure of $\mathbf{8 a}$ to $\mathrm{Sml}_{2}-\mathrm{H}_{2} \mathrm{O}$ gave tetracyclic hemiaminal $\mathbf{9 a}$, containing five contiguous stereocenters in $58 \%$ isolated yield with high diastereocontrol (>95:5 dr) (Table 3). Assessing the scope of the process, a wide variety of substituents including bromo (9b), methoxy (9c and 9f), trifluoromethyl (9d), chloro (9e and $\mathbf{9 g}$ ), naphthyl $(\mathbf{9 h})$ and benzo[b]thiophenyl (9i) were tolerated and products were obtained in moderate to good isolated yield and with universally high diastereocontrol. Finally, 8j bearing a methyl substituent on the cyclopentene unit underwent cascade heterocyclization to give 9j possessing six contiguous stereocenters. The structure of $9 \mathbf{a}$ was confirmed by X-ray crystallographic analysis. ${ }^{[18]}$

Unsymmetrical substrates bearing different groups on nitrogen are easily prepared and can also be used in the cascade. For example, unsymmetrical substrates $9 \mathbf{k}-\mathbf{m}$ bearing recognized protecting groups on nitrogen (vide infra) gave the expected tetracyclic hemiaminal products $\mathbf{9 k} \mathbf{k} \mathbf{m}$ in moderate yield with complete diastereocontrol (Table 3). Interestingly, unsymmetrical $\mathrm{N}$-methyl barbiturate $\mathbf{8 n}$ underwent radical heterocyclization to give enamine $9 \mathrm{n}$ : the hemiaminal product appears to be particularly prone to dehydration in this case. The structure of $9 n$ was confirmed by X-ray crystallographic analysis. ${ }^{[18]}$ Reversible reduction of the amide-type carbonyls likely accounts for the selectivity seen in the reactions of unsymmetrical substrates.

The radical heterocyclization cascade of $9 \mathrm{a}$ proceeds by reductive ET to generate radical 10 (Scheme 4). ${ }^{[15,16]}$ Such radicals bearing $\alpha$-allylsubstituents typically undergo radical fragmentation and deallylation, ${ }^{[22]}$ however, the choice of the cyclopentene moiety is likely to render such a process reversible and ensures radical 10 persists. Diastereoselective 5-exo-trig cyclization then gives rise to secondary benzylic radical intermediate 12 that undergoes a highly selective 6-exo-trig cyclization via a chair transition structure in which the phenyl substituent adopts a pseudoequatorial orientation.

Table 3. Scope of the radical heterocyclization cascade of symmetrical and unsymmetrical amides $\mathbf{8}$ to form hemiaminals $\mathbf{9 a - m}$ or enamine $\mathbf{9 n}$. $^{a, b}$

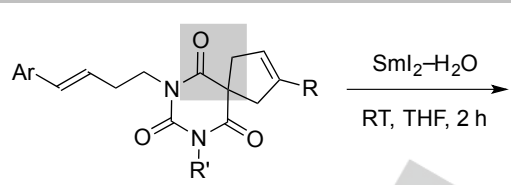

$\mathrm{R}^{\prime}=\mathrm{CH}_{2} \mathrm{CH}_{2} \mathrm{CH}=\mathrm{CHAr} \quad \mathbf{8 a}-\mathbf{n}$ or $\mathrm{R}^{\prime}=$ allyl, cinnamyl, $-\mathrm{CH}_{2} \mathrm{OCH}_{2} \mathrm{CH}_{2} \mathrm{TMS}$
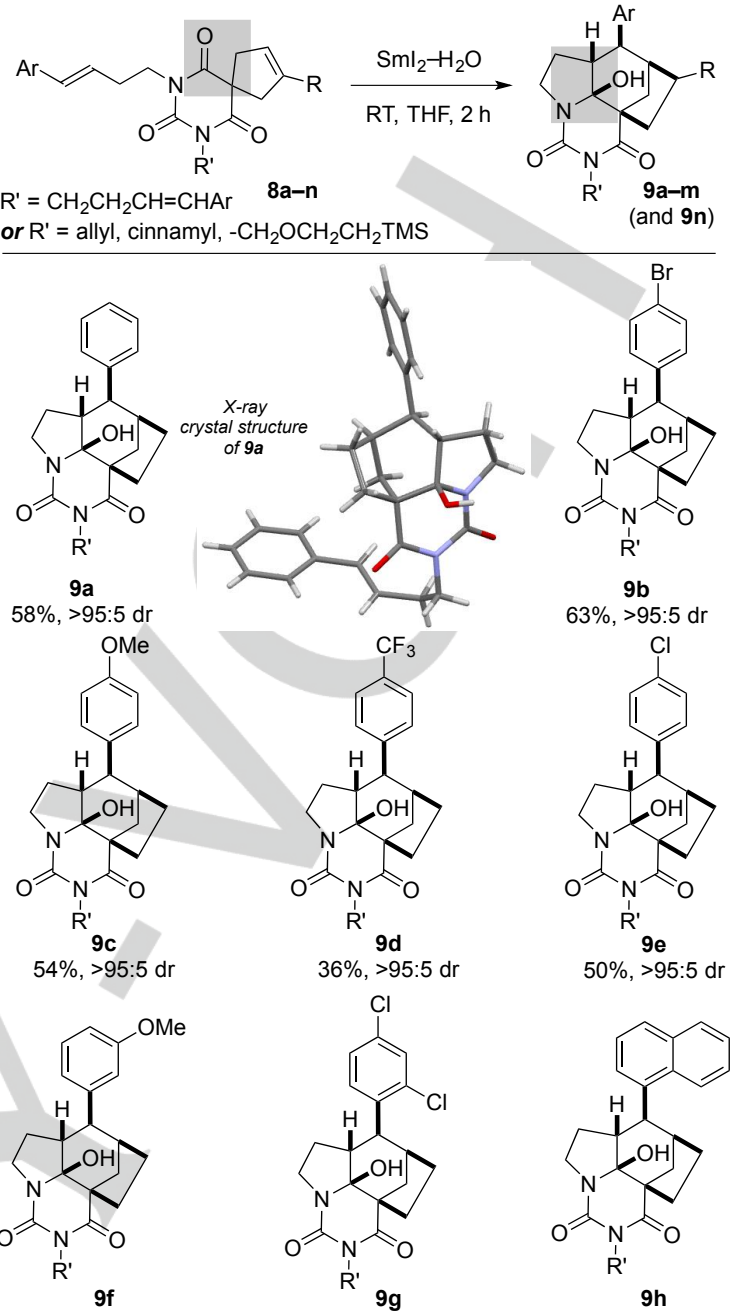

9f
$42 \%,>95: 5 d r$

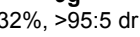

$44 \%,>95: 5 \mathrm{dr}$
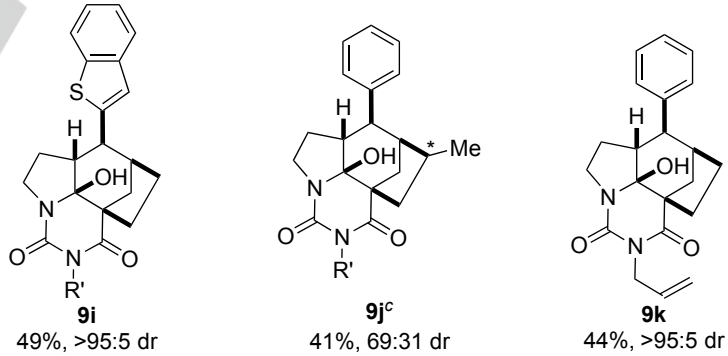

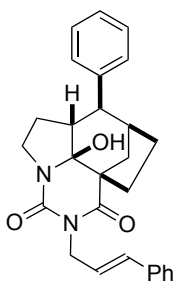

$\mathbf{9 l}^{d}$

$58 \%,>95: 5 \mathrm{dr}$

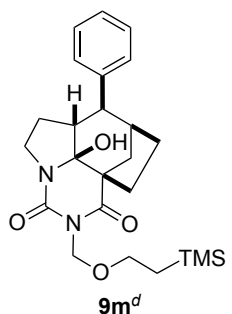

$55 \%,>95: 5 \mathrm{dr}$

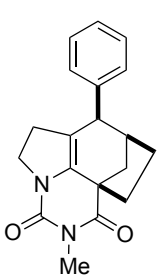

$9 n^{e}$ [a] Reaction conditions: To the substrate $\left(0.1 \mathrm{mmol}\right.$, in THF) under $\mathrm{N}_{2}$ was added $\mathrm{H}_{2} \mathrm{O}$ (100 equiv), followed by slow addition of $\mathrm{Sml}_{2}$ in THF (4 equiv) over $1 \mathrm{~h}$. The reaction was quenched after $1 \mathrm{~h}$. [b] Isolated yields. [c] Diastereoisomeric mixture at highlighted stereocenter. [d] Based on recovered starting material. [e] Dehydrated product was isolated. TMS $=$ trimethylsilyl. 


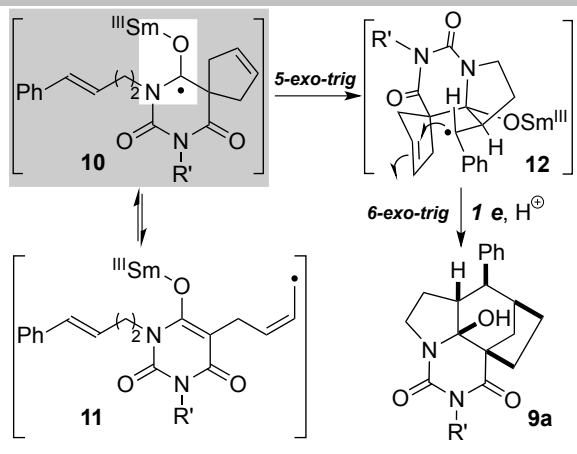

Scheme 4. Proposed mechanism for the radical heterocyclization cascade.

The cinnamyl protecting group in the radical heterocyclization product 9 I could be removed to give the corresponding $\mathrm{N}-\mathrm{H}$ tetracyclic hemiaminal 13 in $55 \%$ isolated yield (Wacker oxidation ${ }^{[21]}$ followed by elimination) (Scheme $5 \mathrm{~A}$ ). Finally, upon treatment of $\mathbf{8 a}$ with the more reducing $\mathrm{Sml}_{2}-\mathrm{H}_{2} \mathrm{O}$ $\mathrm{LiBr}$ system, ${ }^{[23]}$ polycyclic amine 14 was obtained in $40 \%$ isolated yield with high diastereocontrol (Scheme 5B). Thus, the cascade cyclization of $\mathbf{8 a}$ can be selectively switched to form either hemiaminal $\mathbf{9 a}$ or amine $\mathbf{1 4}$ simply through the choice of $\mathrm{LiBr}$ as an additive under otherwise identical reaction conditions. The structure of $\mathbf{1 4}$ was confirmed by X-ray crystallographic analysis ${ }^{[18]}$ and arises from a sequence involving radical heterocyclization cascade, acyl iminium ion formation and reduction.
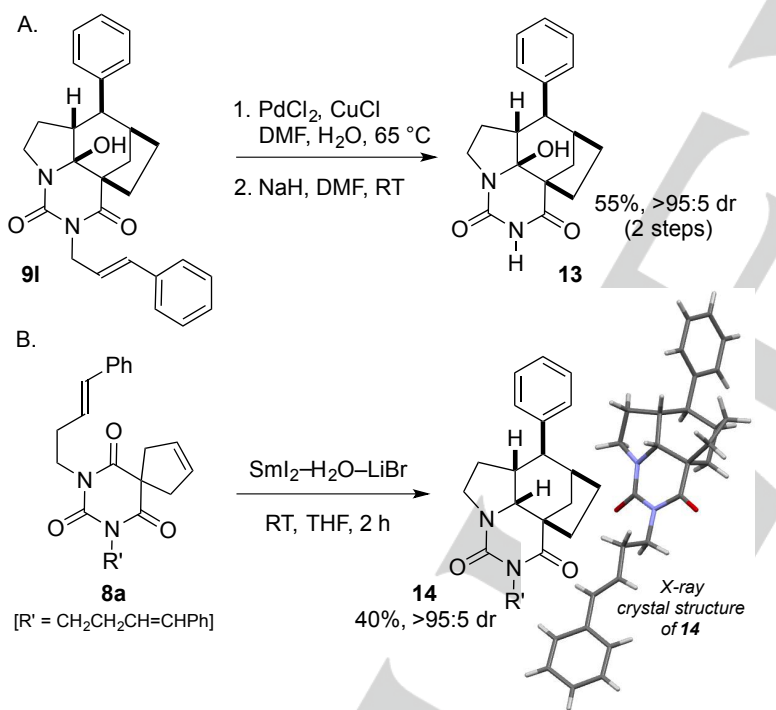

Scheme 5. (A) Deprotection of nitrogen in a radical heterocyclization cascade product. (B) Sequential radical heterocyclization cascade, iminium ion formation and selective reduction.

In conclusion, radical heterocyclizations triggered by electron transfer to amide-type carbonyls using $\mathrm{Sml}_{2}-\mathrm{H}_{2} \mathrm{O}$ provide straightforward access to bicyclic heterocyclic scaffolds containing bridgehead nitrogen atoms. Furthermore, the first radical heterocyclization cascades triggered by reduction of amide-type carbonyls deliver complex tetracyclic architectures containing five contiguous stereocenters with excellent diastereocontrol.

\section{Acknowledgements}

We thank the EPSRC (EPSRC Established Career Fellowship to D. J. P.), the Leverhulme Trust (Research Fellowship to D. J. P.), and the University of Manchester (President's Scholarship to $\mathrm{H}$. H.).

Keywords: radical $\cdot$ samarium diiodide $\cdot$ heterocyclization $•$ cascade $\cdot$ amides

[1] Selected reviews, see: a) J. A. Joule, K. Mills, Heterocyclic Chemistry, Wiley, 2010; b) J. P. Michael, Nat. Prod. Rep. 2002, 19, 719; c) M. Szostak, J. Aubé, Chem. Rev. 2013, 113, 5701; d) P. A. Evans, B. Holmes, Tetrahedron 1991, 47, 9131. Selective examples of bicyclic nucleobase scaffolds, see: e) Y. Zhang, J. Zheng, S. Cui, J. Org. Chem. 2014, 79, 6490; f) M. Mizuta, K. Seio, K. Miyata, M. Sekine, J. Org. Chem. 2007, 72, 5046; g) I. López, A. Diez, M. Rubiralta, Tetrahedron 1996, 52, 8581; h) V. T. Bandurco, E. M. Wong, S. D. Levine, Z. G. Hajos, J. Med. Chem. 1981, 24, 1455. Selective examples and review of kopsifoline B and C, see: i) T. S. Kam, Y. M. Choo, Tetrahedron Lett. 2003, 44, 1317; j) T. Kam, Y. Choo, Helv. Chim. Acta 2004, 87, 991; k) J. E. Sears, D. L. Boger, Acc. Chem. Res. 2016, 49, 241. Selective examples of (+)-fendleridine and (+)-acetylaspidoalbidine, see: I) E. L. Campbell, A. M. Zuhl, C. M. Liu, D. L. Boger, J. Am. Chem. Soc. 2010, 132, 3009; m) K. L. White, M. Movassaghi, J. Am. Chem. Soc. 2016, 138, 11383. Selective examples and review of strychnine, see: $n)$ R. B. Woodward, M. P. Cava, W. D. Ollis, A. Hunger, H. U. Daeniker, K. Schenker, J. Am. Chem. Soc. 1954, 76, 4749; o) C. Beemelmanns, H.U. Reissig, Angew. Chem., Int. Ed. 2010, 49, 8021; Angew. Chem. 2010, 122, 8195; p) M. Szostak, D. J. Procter, Angew. Chem., Int. Ed. 2011, 50, 7737; Angew. Chem. 2011, 123, 7881; q) J. Bonjoch, D. Solé, Chem. Rev. 2000, 100, 3455; r) J. S. Cannon, L. E. Overman, Angew. Chem., Int. Ed. 2012, 51, 4288; Angew. Chem. 2012, 124, 4362.

[2] Selected reviews on the synthesis of heterocycles, see: a) V. Eschenbrenner-Lux, K. Kumar, H. Waldmann, Angew. Chem., Int. Ed. 2014, 53, 11146; Angew. Chem. 2014, 126,11326; b) N. Krause, C. Winter, Chem. Rev. 2011, 111, 1994; c) N. R. Candeias, L. C. Branco, P. M. P. Gois, C. A. M. Afonso, A. F. Trindade, Chem. Rev. 2009, 109, 2703; d) N. T. Patil, Y. Yamamoto, Chem. Rev. 2008, 108, 3395; e) M. Álvarez-Corral, M. Muñoz-Dorado, I. Rodríguez-García, Chem. Rev. 2008, 108, 3174; f) J. C. Lewis, R. G. Bergman, J. A. Ellman, Acc. Chem. Res. 2008, 41, 1013; g) K. R. Campos, Chem. Soc. Rev. 2007, 36, 1069; h) D. M. D'Souza, T. J. J. Müller, Chem. Soc. Rev. 2007, 36, 1095; i) G. Zeni, R. C. Larock, Chem. Rev. 2004, 104, 2285; j) A. Gansäuer, T. Lauterbach, S. Narayan, Angew. Chem., Int. Ed. 2003, 42, 5556; Angew. Chem. 2003, 115, 5714.

[3] For a review see 1k. For a selected example, see: K. Lee, D. L. Boger, J. Am. Chem. Soc. 2014, 136, 3312.

[4] X. Hong, S. France, J. M. Mejía-Oneto, A. Padwa, Org. Lett. 2006, 8, 5141.

[5] Y. Li, Q. Zhang, Q. Du, H. Zhai, Org. Lett. 2016, 18, 4076.

[6] An excellent example of radical cyclization to build tricyclic alkaloids, see: A. D. Gammack Yamagata, D. J. Dixon, Org. Lett. 2017, 19, 1894. Selected reviews, see: a) M. Yan, J. C. Lo, J. T. Edwards, P. S. Baran, J. Am. Chem. Soc. 2016, 138, 12692; b) J. Streuff, A. Gansäuer, Angew. Chem., Int. Ed. 2015, 54, 14232; Angew. Chem. 2015, 127, 14438; c) G. J. Rowlands, Tetrahedron 2010, 66, 1593; d) G. J. Rowlands, Tetrahedron 2009, 65, 8603; e) K. C. Majumdar, P. K. Basu, P. P. Mukhopadhyay, Tetrahedron 2004, 60, 6239; f) K. K. Wang, Z. Wang, A. Tarli, P. Gannett, J. Am. Chem. Soc. 1996, 118, 10783.

[8] Selected leading reviews in Sm(II) chemistry, see: a) X. Just-Baringo, D. J. Procter, Acc. Chem. Res. 2015, 48, 1263; b) M. Szostak, N. J. Fazakerley, D. Parmar, D. J. Procter, Chem. Rev. 2014, 114, 5959; c) M. Szostak, M. Spain, D. J. Procter, Chem. Soc. Rev. 2013, 42, 9155; d) M. Szostak, M. Spain, D. Parmar, D. J. Procter, Chem. Commun. 2012, 48, 330; e) M. Szostak, D. J. Procter, Angew. Chem., Int. Ed. 2012, 51, 9238; Angew. Chem. 2012, 124, 9372. f) C. Beemelmanns, H.-U. Reissig, Chem. Soc. Rev. 2011, 40, 2199; g) C. Beemelmanns, H.-U. Reissig, Pure Appl. Chem. 2011, 83, 507; h) K. C. Nicolaou, S. P. Ellery, J. S. Chen, Angew. Chem., Int. Ed. 2009, 48, 7140; Angew. Chem. 2009, 121, 7276; i) D. J. Procter, R. A. Flowers II, T. Skrydstrup, 
Organic Synthesis using Samarium Diiodide: A Practical Guide, RSC Publishing, Cambridge, 2010; j) R. A. Flowers II, Synlett 2008, 1427; k) D. J. Edmonds, D. Johnston, D. J. Procter, Chem. Rev. 2004, 104 3371; I) H. Kagan, Tetrahedron 2003, 59, 10351; m) A. Krief, A.-M Laval, Chem. Rev. 1999, 99, 745; n) G. A. Molander, C. R. Harris, Chem. Rev. 1996, 96, 307.

[9] Selected reviews on Sm(II)-mediated ET to carboxylic acid derivatives, see: $\mathbf{8 a}$ and $\mathbf{8 d}$. For recent reports of the carbocyclization and cascade of lactone derivatives, see: a) X. Just-Baringo, J. Clark, M. J. Gutmann D. J. Procter, Angew. Chem., Int. Ed. 2016, 55, 12499; Angew. Chem. 2016, 128,12687; b) D. Parmar, H. Matsubara, K. Price, M. Spain, D. J. Procter, J. Am. Chem. Soc. 2012, 134, 12751; c) P. A. . Parmar, D. Price, K.; Spain, M.; Matsubara, H.; Bradley, D. J. Procter, D. Parmar K. Price, M. Spain, H. Matsubara, P. A. Bradley, D. J. Procter, J. Am. Chem. Soc. 2011, 133, 2418. Selective examples of carbocyclization and cascade of Meldrum's acid derivatives, see: d) B. Sautier, S. E. Lyons, M. R. Webb, D. J. Procter, Org. Lett. 2012, 14, 146; e) K. D. Collins, J. M. Oliveira, G. Guazzelli, B. Sautier, S. De Grazia, H. Matsubara, M. Helliwell, D. J. Procter, Chem. -Eur. J. 2010, 16, 10240.

[10] a) C. L. Allen, J. M. J. Williams, Chem. Soc. Rev. 2011, 40, 3405; b) E. Valeur, M. Bradley, Chem. Soc. Rev. 2009, 38, 606.

[11] Selective recent examples, see: a) C. N. Rao, C. Bentz, H.-U. Reissig, Chem. -Eur. J. 2015, 21, 15951; b) C. Beemelmanns, H.-U. Reissig Chem. -Eur. J. 2015, 21, 8416; c) C. N. Rao, D. Lentz, H.-U. Reissig, Angew. Chem., Int. Ed. 2015, 54, 2750; Angew. Chem. 2015, 127 2788; d) C. Beemelmanns, S. Gross, H. U. Reissig, Chem. -Eur. J. 2013, 19, 17801; e) C. Beemelmanns, D. Lentz, H.-U. Reissig, Chem. Eur. J. 2011, 17, 9720; f) S. Gross, H.-U. Reissig, Org. Lett. 2003, 5, 4305. See also ref. 10

[12] a) R. H. Taaning, L. Thim, J. Karaffa, A. G. Campaña, A.-M. Hansen, T. Skrydstrup, Tetrahedron 2008, 64, 11884; b) J.-P. Ebran, C. M. Jensen, S. A. Johannesen, J. Karaffa, K. B. Lindsay, R. Taaning, T. Skrydstrup, Org. Biomol. Chem. 2006, 4, 3553; c) M. F. Jacobsen, M. Turks, R. Hazell, T. Skrydstrup, J. Org. Chem. 2002, 67, 2411.

[13] a) C.-P. Xu, P.-Q. Huang, S. Py, Org. Lett. 2012, 14, 2034; b) P. Gilles S. Py, Org. Lett. 2012, 14, 1042; c) S. Desvergnes, S. Py, Y. Vallée, J. Org. Chem. 2005, 70, 1459.

[14] a) X. K. Liu, S. Qiu, Y. G. Xiang, Y. P. Ruan, X. Zheng, P. Q. Huang, J. Org. Chem. 2011, 76, 4952; b) Y.-G. Xiang, X.-W. Wang, X. Zheng, Y.P. Ruan, P.-Q. Huang, Chem. Commun. 2009, 10, 7045.

[15] For the first example of radical carbocyclization of amide-type carbonyls, see: M. Szostak, B. Sautier, M. Spain, M. Behlendorf, D. J. Procter Angew. Chem., Int. Ed. 2013, 52, 12559; Angew. Chem. 2013, 125 12791.

[16] For the first radical carbocyclization cascades of amides, see: a) H.-M. Huang, D. J. Procter, J. Am. Chem. Soc. 2016, 138, 7770; b) H.-M. Huang, D. J. Procter, J. Am. Chem. Soc. 2017, 139, 1661; c) H.-M. Huang, P. Bonilla, D. J. Procter, Org. Biomol. Chem. 2017, 15, 4159 For examples of the carbo and heterocyclization of imides, see: (d) S Shi, M. Szostak, Org. Lett. 2015, 17, 5144; e) S. Shi, R. Lalancette, R. Szostak, M. Szostak, Chem. -Eur. J. 2016, 22, 11949; f) S. Shi, R. Lalancette, M. Szostak, Synthesis 2016, 1825.

[17] See the Supporting Information for details

[18] See supporting information for $X$-ray structures and CCDC numbers (CCDC 1536045 for 2n, CCDC 1545501 for 9a, CCDC 1545502 for 9n, CCDC 1545503 for 14). These data can be obtained free of charge from The Cambridge Crystallographic Data Centre.

[19] a) J. Royer, M. Bonin, L. Micouin, Chem. Rev. 2004, 104, 2311; b) B. E. Maryanoff, H. C. Zhang, J. H. Cohen, I. J. Turchi, C. A. Maryanoff, Chem. Rev. 2004, 104, 1431.

[20] For selected reviews on cascade reactions, see: a) E. A. Anderson, Org. Biomol. Chem. 2011, 9, 3997; b) K. C. Nicolaou, J. S. Chen, Chem. Soc. Rev. 2009, 38, 2993; c) K. C. Nicolaou, D. J. Edmonds, P. G. Bulger, Angew. Chem., Int. Ed. 2006, 45, 7134; Angew. Chem. 2006, 118, 7292; d) L. F. Tietze, Chem. Rev. 1996, 96, 115.

[21] a) J. Smidt, W. Hafner, R. Jira, J. Sedlmeier, R. Sieber, R. Rüttinger, H. Kojer, Angew. Chem. 1959, 71, 176; b) J. Smidt, W. Hafner, R. Jira, R Sieber, J. Sedlmeier, A. Sabel, Angew. Chem. 1962, 74, 93; c) J. Tsuji, Synthesis. 1984, 1984, 369; d) M. S. Sigman, E. W. Werner, Acc. Chem. Res. 2012, 45, 874; e) C. N. Cornell, M. S. Sigman, Inorg. Chem. 2007, 46, 1903.
[22] For selected examples of related fragmentations, see: a) Q. Xu, B Cheng, X. Ye, H. Zhai, Org. Lett. 2009, 11, 4136; b) T. K. Hutton, K. Muir, D. J. Procter, Org. Lett. 2002, 4, 2345; c) A. Haque, Chem. Commun. 1997, 2039. See also ref. 16a.

[23] $\mathrm{SmBr}_{2}$ (approximately $-1.55 \mathrm{~V}$ vs $\mathrm{SCE}$ ) has a higher reduction potential than $\mathrm{Sml}_{2}$ ( $-0.9 \mathrm{~V}$ vs SCE), see related reports: a) B. W. Knettle, R. A. Flowers II, Org. Lett. 2001, 3, 2321; b) R. S. Miller, J. M. Sealy, M. Shabangi, M. L. Kuhlman, J. R. Fuchs, R. A. Flowers II, J. Am. Chem. Soc. 2000, 122, 7718; c) J. R. Fuchs, M. L. Mitchell, M. Shabangi, R. A. Flowers II, Tetrahedron Lett. 1997, 38, 8157. For the effective redox potential of $\mathrm{SmBr}_{2}-\mathrm{H}_{2} \mathrm{O}$, see: d) M. Szostak, M. Spain, D. J. Procter, J. Org. Chem. 2014, 79, 2522. 
Entry for the Table of Contents (Please choose one layout)

Layout 2:

\section{COMMUNICATION}

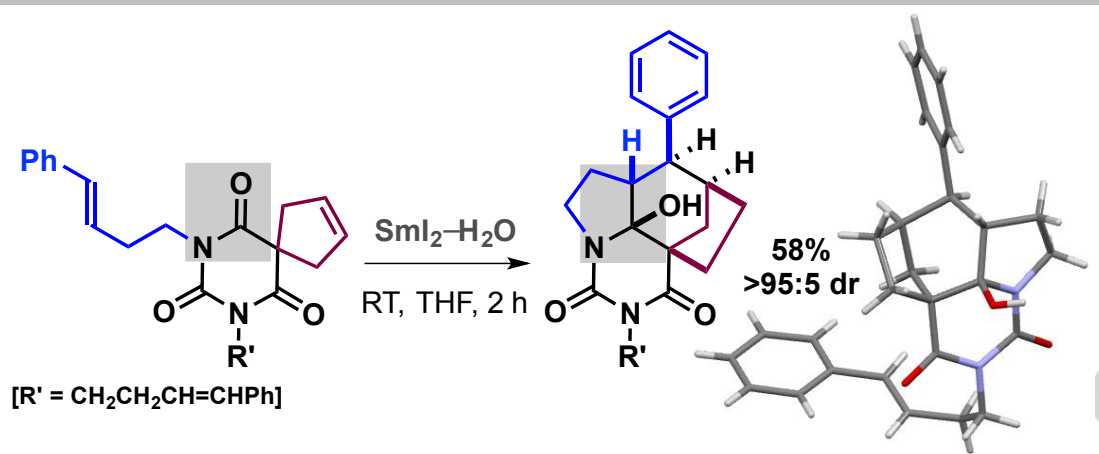

Huan-Ming Huang and David J. Procter*

Page No. - Page No.

Radical heterocyclization and heterocyclization cascades triggered by electron transfer to amide-type carbonyls

Radical heterocyclization and heterocyclization cascades triggered by electron transfer to amide-type carbonyls provides straightforward access to heterocyclic scaffolds containing bridgehead nitrogen atoms. The radical cascade cyclizations deliver novel tetracyclic architectures containing five contiguous stereocenters with excellent diastereocontrol. 